\section{A new journal}

Editor-in-Chief: Gerald Stanhill, Agricultural Research Organization, The Volcani Center, Institute of Soils and Water, P.O.B. 6, Bet Dagan, Israel

Editors: J.F. Bierhuizen, Department of Horticulture, Agricultural University, Haagsteeg 3, Wageningen, The Netherlands; Th.C. Hsiao, Department of Water Science, University of California, Davis, CA 95616, USA; M.E. Jensen, The Director, Soil and Water Conservation Laboratory, A.R.S., U.S.D.A., Kimberly, ID 83341, USA; St.L. Rawlins, U.S. Salinity Laboratory, P.O.B. 672, Riverside, CA 92501, USA; C.W. Rose, School of Australian Environmental

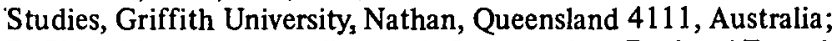
D. Shimshi, Agricultural Research Organization, Regional Experiment Station, Mobile Post Negev 2, Gilat, Israel; B. Slavik, Czechoslovak Academy of Siences, Institute of Experimental Botany, Department of Plant Physiology, Flemingovo Nám. 2, Praha 6, Czechoslovakia

Irrigation Science will publish original contributions and short communications reporting the results. of irrigation research, including relevant contributions from the plant, soil and atmospheric sciences as well as the analysis of field experimentation. Special emphasis will be given to multi-disciplinary studies dealing with the problems involved in maintaining the long term productivity of irrigated lands and in increasing the efficiency of agricultural water use.

Aspects of particular interest are:

- Physical and chemical aspects of water status and movement in the plant-soil-atmosphere system.

- Physiology of plant growth and yield response to water status.

- Plant-soil-atmosphere and water management in irrigation practice.

- Measurement, modification and control of crop water requirements.

- Salinity and alkalinity control by. soil and water management.

- Ecological aspects of irrigated agriculture.

Subscription Information

Volume 1 (4 issues) will appear in 1977. Sample copies available upon request.

All countries (except North America)

1977: DM 148,-, plus postage and handling. Send your order or requèst to your bookseller or directly to: Springer-Verlag, Wișsenschaftliche Information Zeitschriften, Postfach 105280, D-6900 Heidelberg, F.R.G.

\section{North America}

1977: US $\$ 63.40$, including postage and handling. Subscriptions are entered with prepayment only. Send your order or request to your bookseller or directly to: Springer-Verlag New York Inc., 175 Fifth Avenue, New York, NY 10010, USA

\section{Springer International}

(i) 


\section{THE \\ JOURNAL OF \\ AGRICULTURAL SCIENCE}

EDITED BY

Prof. J. W. L. BEAMENT, sC.D., F.R.S., Department of Applied Biology, Cambridge

G. D. H. BELL, C.B.E., PH.D., F.R.s. Plant Breeding Institute, Cambridge

K. L. BLAXTER, PH.D., N.D.A. (HONS.), D.SC., F.R.S.E., F.R.S.,

Rowett Research Institute, Bucksburn, Aberdeen

G. W. COOKE, PH.D., F.R.I.C., F.R.S., Agricultural Research Council, 160 Great Portland Street, London W1N 6DT

S. K. ELTRINGHAM, PH.D., Department of Applied Biology, Cambridge

Prof. Sir J. B. HUTCHINSON, C.M.G., SC.D., F.R.S., Emeritus Professor of

Agriculture, Department of Applied Biology, Cambridge

Prof. J. B. OWEN, B.SC., PH.D., M.A., School of Agriculture, Aberdeen

H. L. PENMAN, O.B.B., PH.D., F.R.S., Rothamsted Experimental Station, Harpenden

Prof A. T. PHILLIPSON, PH.D., M.R.C.v.S., F.R.S.E., Department of Clinical Veterinary Medicine, Cambridge

W. J. RIDGMAN, M.A., Department of Applied Biology, Cambridge

H. H. ROGERS, B.SC., DIP.AG.SCI., Plant Breeding Institute, Cambridge

L. E. A. ROWSON, O.B.E., M.R.C.V.S., F.R.S., Agricultural Research Council, Unit of

Reproductive Physiology and Biochemistry, Animal Research Station,

Cambridge

Prof. E. W. RUSSELL, C.M.G., PH.D., F.INST.P., Department of Soil Science,

University of Reading

F. YATES, C.B.E., SC.D., F.R.S., Rothamsted Experimental Station, Harpenden

VOLUME 88

CAMBRIDGE UNIVERSITY PRESS

CAMBRIDGE · LONDON · NEW YORK

1977 


\section{PUBLISHED BY}

THE SYNDICS OF THE CAMBRIDGE UNIVERSITY PRESS

The Pitt Building, Trumpington Street, Cambridge CB2 1RP

Bentley House, 200 Euston Road, London, NW1 2DB

32 East 57th Street, New York, N.Y.10022

(C) Cambridge University Press 1977 


\section{Contents}

\section{Part 1 (February 1977)}

Keluaway, R. C., Thomson, D. J., Begver, D. E. and Osbourn, D. F. Effects of $\mathrm{NaCl}$ and $\mathrm{NaHCO}_{3}$ on food intake, growth rate and acid-base balance in calves . . . .

PAGE

LEDGER, H. P. and SAYERS, A. R. The utilization of dietary energy by steers during periods of restricted food intake and subsequent realimentation. 1. The effect of time on the maintenance requirements of steers held at constant live weights .

LEDGER, H. P. The utilization of dietary energy by steers during periods of restricted food intake and subsequent realimentation. 2. The comparative energy requirements of penned and exercised steers for long term maintenance at constant live weight . .

Widdowson, F. V. and Penny, A. Results from two sets of experiments with spring barley, the first comparing injected with broadcast nitrogen granules, the second comparing injected and combine-drilled NPK solutions with broadcast NPK granules .

Innes, N. L. and Jones, G. B. Performance of seed mixtures and multilines of Upland cotton in Uganda

Khattab, A. H., Kramfa, H. and El Thray, A. H. Chemical composition of seeds of some species of the genus Gossypium

Befver, D. E., Thomson, D. J., Cammell, S. B. and Harrison, D. G. The digestion by sheep of silages made with and without the addition of formaldehyde .

Riтонге, N. S. and Fisнwick, G. Magnesium phosphate as a dietary supplement for lactating cows at spring pasture .

Sharma, V. V. and RAJORA, N. K. Voluntary intake and nutrient digestibility of low-grade roughage by ruminants .

JoHnson, C. L. The effect of the plane and pattern of concentrate feeding on milk yield and composition in dairy cows

BASSIRI, A., KHOSH-KHUI, M. and RoUHANI, I. The influences of simulated moisture stress conditions and osmotic substrate on germination and growth of cultivated and wild safflowers

Gerritse, R. G. and Zuged, I. The phosphorus cycle in pig slurry measured from ${ }^{32} \mathrm{PO}_{4}$ distribution rates.

Adeneye, J. A., Bamiduro, T. A., Adebanjo, Adetowun K. and Aknryemi, A. A. Factors affecting birth weight of Holstein-Friesian calves in Western Nigeria

WELCH, R. W. Seedling vigour and grain yield of cereals grown from seeds of varying protein contents

England, F. Response to family selection based on replicated trials

FоOт, J. Z. and TULLOH, N. M. Effects of two paths of live-weight change on the efficiency of feed use and on body composition of Angus steers

Fishwiok, G., Fraser, J., Hemingway, R. G., Parkins, J. J. and Ritchie, N. S. The effects of dietary phosphorus inadequacy during pregnancy and lactation on the voluntary intake and digestibility of oat straw by beef cows and the performance of their calves . 
TAYo, T. O. Comparative analysis of the growth, development and yield of three soya-bean varieties (Glycine $\max \mathrm{L}$.)

Austin, R. B., Ford, N. A., Edrioh, J. A. and Blackwell, R. D. The nitrogen economy of winter wheat.

159

Hegarty, T. W. Seed vigour in field beans (Vicia faba L.) and its influence on plant stand

Leat, W. M. F., Kemp, P., Lysons, R. J. and Alexander, T. J. L. Fatty acid composition of depot fats from gnotobiotic lambs

Tagari, H. and Ben-Ghidalia, D. The digestibility of Rhodes grass (Chloris gayana) in relation to season and proportion of the diet of sheep .

Faturla, T. and Sald, A. Breeding for resistance to root-knot nematodes in tomatoes

Kempster, A. J. and Jones, D. W. Relationships between the lean content of joints and overall lean content in steer carcasses of different breeds and crosses . . . .

Arora, B. R. and Sekron, G. S. Evaluation of soil tests for the estimation of available sulphur

Furnival, E. P., Corbett, J. L. and Shorthouse, W. R. Meat properties of lambs grown to $32 \mathrm{~kg}$ at various rates on phalaris or lucerne pastures and an apparent effect on preslaughter ambient temperature

Morr, K. W., WIISON, J. R. and BLIGHT, G. W. The in vitro digested cell wall and fermentation characteristics of grasses as affected by temperature and humidity during their growth

Yeates, N. T. M. The coat and heat retention in cattle: studies in the tropical maritime climate of Fiji

SHORT NOTES

OJомо, O. A. Morphology and genetics of two gene markers, 'Swollen stem base' and 'Hastate leaf' in cowpea, Vigna unguiculata (L.) Walp.

LAwrence, T. L.J. and BoyD, J.W. Growth responses and serum enzyme activities in growing pigs resultant from supplementing diets based on aged barley with synthetic $\delta$ - $\alpha$-tocopherol

Verma, D. N. and SINGH, U. B. Digestibility of rumen bacterial cell proteins in buffaloes and goats

Whittemore, C. T. and Moffat, I. W. Performance of growing pigs fed dried microbial cells (Methylomonas methylotropha)

Wrison, S. and Macrae, J. C. An investigation into the loss of activity of ${ }^{14} \mathrm{C}$-labelled volatile fatty acid (VFA) tracers used to measure VFA production rates in the rumen of sheep

Wrison, G. P. M. and Hennessy, D. W. The germination of excreted kikuyu grass seed in cattle dung pats

Bari KHaN, M. A. and TaldKdar, A. H. Follicle population in Black Bengal goats . 251

Poulsen, M. H. Obligate autogamy in Vicia faba L. . . . . . . . . . . . . . $\quad$. 253 
Dmulon, B. S. and Snvar, J. Estimation and inheritance of stability parameters of grain yield in maize

JoNEs, H. G. Aspects of the water relations of spring wheat (Triticum aestivum $\mathrm{L}$.) in response to induced drought

Mackre, W. S. Changes in the concentration of plasma proteins in intensively bred ewes .

RICHARDS, I. R. and Hobson, R. D. The relationship between nitrogen supply and the nitrogen yield of cut grass swards .

Sprent, J. I., Bradford, A. M. and Norton, C. Seasonal growth patterns in field beans (Vicia $f a b a)$ as affected by population density, shading and its relationship with soil moisture

Sprent, J. I. and Bradford, A. M. Nitrogen fixation in field beans (Vicia faba) as affected by population density, shading and its relationship with soil moisture

ONwUEme, I. C. Field comparison of West African planting and harvesting practices in yam (Dioscorea rotundata): pre-sprouting, dry season planting, and double-harvesting .

Penny, A., Widnowson, F. V. and Ashworth, J. Results from an experiment on permanent grass evaluating aqueous ammonia and aqueous urea, injected in bands either 30 or $60 \mathrm{~cm}$ apart .

Wood, P. D. P. The biometry of lactation

Carles, A. B. and Lampkrn, K. Medie. Studies of the permanent incisor eruption, and body development of the Large East African Zebu (Boran). 1. The ages of first appearance of the incisors, lengths of the incisor eruption period, and sources of variation

Carles, A. B. and Lampkin, K. Meidie. Studies of the permanent incisor eruption, and body development, of the Large East African Zebu (Boran). 2. Relations of incisor eruption with body growth, body development and carcass composition

Gutrais, R. A. Crossing Merino and a coarse wool breed of sheep, a study of the birthcoat of lambs

KIRBY, E. J. M. and JoNes, H. G. The relations between the main shoot and tillers in barley plants .

JoNES, H. G. and KmRBY, E. J. M. Effects of manipulation of number of tillers and water supply on grain yield in barley

VALdez Espinosa, R., Robrnson, J. J. and Scotr, D. The effect of different degrees of food restriction in late pregnancy on nitrogen metabolism in ewes

Norrington-Davies, J. and Harries, J. H. Competition studies in diploid and tetraploid varieties of Lolium perenne. I. The influence of density and proportion of sowing .

Harries, J. H. and Norrington-Davies, J. Competition studies in diploid and tetraploid varieties of Lolium perenne. II. The inhibition of germination

RAO, V.S., GangwaR, M. S. and RathoRe, V. S. Genotypic variation in distribution of total and labelled zinc and availability of zinc ( $A$ and $L$ values) to soya beans grown in Mollisol

ENy, B. A. C. Analysis of growth and tuber yield in sweet potato (Ipomoea batatas) cultivars 
Pidgeon, J. D. and Soane, B. D. Effects of tillage and direct-drilling on soil properties during the growing season in a long-term barley mono-culture system .

AвoUl-NaGA, A. M. and AFIFi, E. A. Environmental and genetic factors affecting wool production from sub-tropical coarse wool sheep .

Hammerton, J.L. Predicting dry weights of pigeon-pea plants from non-destructive measurements

Webster, R., Hodge, C. A. H., Draycott, A. P. and Durrant, M. J. The effect of soil type and related factors on sugar beet yield.

Ryder, M. L. The pre-natal development of skin follicles in Mouflon (Ovis musimon) $\times$ Soay, Soay and Shetland sheep

Powley, G. and JoHNsor, C. L. Some effects of conservation of grass upon magnesium metabolism in sheep

WIIMAN, D. The effect of grazing compared with cutting at different frequencies, on a lucerne-cocksfoot ley

WHTт, R. W. In vivo inhibition by specific lipids of ethanol production from glucose by the yeast Torulopsis glabrata

Grafam, P. H. and Rosas, J. C. Growth and development of indeterminate bush and climbing cultivars of Phaseolus vulgaris L. inoculated with Rhizobium

SHORT Note

Kradifa, M. A. Studies on the breeding system of Alexandrian Senna (Cassia acutifolia Del.)

Benjamm, R. W., Chen, M., Degen, A. A., Abdul Aziz, N. and Al Hadad, M. J. Estimation of the dry and organic matter intake of young sheep grazing in a dry Mediterranean pasture and their maintenance requirements

Agees, 0. A. A. and Ayoub, A. T. Effect of sowing date and soil type on plant survival and grain yield of chick peas (Cicer arietinum $\mathrm{L}$.)

Ashton, W. M., Williams, Myrtle and Ingleton, Jean. Studies on ewe's milk. VI. The content of some trace elements

Litille, D. A., McLean, R. W. and Winter, W. H. Prediction of the phosphorus content of herbage consumed by grazing cattle

Robinson, J. J., McDonald, I., Fraser, C. and Crofts, R. M. J. Studies on reproduction in Prolific ewes. 1. Growth of the products of conception .

WeNhaM, G. Studies on reproduction in prolific ewes. 2. A radiographic study of the primary and secondary ossification centres in the foetus

SCARISBRICK, D. H., WHKKES, J. M. and KemPSON, R. The effect of varying plant population density on the seed yield of Navy beans (Phaseolus vulgaris) in south-east England .

Penning, P. D., Penning, Ines, M. and Treacher, T. T. The effect of temperature and method of feeding on the digestibility of two milk substitutes and on the performance of lambs 
Singh, Ranjodh, Chadha, R. K., Verma, H. N. and Singh, Yavdinder. Response of dryland wheat to phosphorus fertilization as infiuenced by profile water storage and rainfall .

Lysons, R. J., Alexander, T. J. L. and Wellstead, Patricia, D. Nutrition and growth of gnotobiotic lambs.

HebblethwaITe, P. D. Irrigation and nitrogen studies in S. 23 ryegrass grown for seed. 1. Growth, development, seed yield components and seed yield

Hebblethwatte, P. D. and McGowaN, M. Irrigation and nitrogen studies in S. 23 ryegrass grown for seed. 2. Crop transpiration and still-water status

Hundax, H. S., Deol, P. S. and Sekhon, G. S. Evaluation of some sources of fertilizer phosphorus in two cycles of a paddy-wheat cropping sequence

Hodgson, D. R., Prodd, J. R. and Browne, S. Cultivation systems for spring barley with special reference to direct drilling (1971-1974)

MEHREZ, A. Z. and ØRSKOv, E. R. A study of the artificial fibre bag technique for determining the digestibility of feeds in the rumen.

Farmy, M. H. and Vesely, J. A. Wool yield and characteristics of Dorset, Leicester and Suffolk breeds and their 'DLS' cross

Fetuga, B. L., Babatunde, G. M. and Oyendga, V. A. The value of palm kernel meal in finishing diets for pigs. 1. The effect of varying the proportion of protein contribution from blood meal and palm kernel meal on the performance and carcass quality of finishing pigs

Fetuga, B. L., Babatunde, G. M. and Oyenuga, V. A. The value of palm kernel meal in finishing diets for pigs. 2 . The effects of the addition of cane molasses on the utilization of high level palm-kernel meal diets

SykEs, A. R. and Coop, R. L. Intake and utilization of food by growing sheep with abomasal damage caused by daily dosing with Ostertagia circumcincta larvae

Obigbesan, G. O., Kertku, A. O. and FAyem, A. A. Effects of age at harvest and fertilizer application on the yield, available carbohydrates and hydrocyanic acid content of cassava (Manihot palmata Pohl).

Armstrong, R. H. and EAdIE, J. The growth of hill lambs on herbage diets

Degen, A. A. Fat-tailed Awassi and German Mutton Merino sheep under semi-arid conditions. 1. Total body water, its distribution and water turnover

Degen, A. A. Fat-tailed Awassi and German Mutton Merino sheep under semi-arid conditions. 2. Total body water and water turnover during pregnancy and lactation

Mussa, A. E. A. and Russel, P. E. The influence of pesticides and herbicides on the growth and virulence of Fusarium solani f.sp. phaseoli

Bartholomew, P. W. and Chestnutr, D. M. B. The effect of a wide range of fertilizer nitrogen application rates and defoliation intervals on the dry-matter production, seasonal response to nitrogen, persistence and aspects of chemical composition of perennial rye. grass (Lolium perenne cv. S. 24)

Badhoria, B. S., Aggarwal, G. C. and Tripathi, B. R. An inexpensive device for recording seedling emergence force 
Smithson, J. B. and Gridley, H. E. Oil content of cotton seed in Northern Nigeria. 1. Assessment of nuclear magnetic resonance for the determination of the oil percentage of cotton seed

Gridley, H. E. and Smithson, J. B. Oil content of cotton seed in Northern Nigeria. 2. Varietal and environmental variation

ONwUEMe, I. C. Effect of varying the time of the first harvest, and of late planting on doubleharvest yield of yam (Dioscorea rotundata) in field plots . . . . . .

El-Karourr, M. O. H. and Gooderham, P. T. The effect of soil physical conditions and nitrogen fertilizer on the yield of Italian ryegrass .

BeDI, A. S. and SekHon, G. S. Effect of potassium and magnesium application to soils on the dry-matter yield and cation composition of maize

DAHIYA, B. S., BRAR, J. S. and BAJAJ, R. K. Regressions, correlations and combining ability of some quantitative characters in peas (Pisum sativum L.) .

Wright, P. C., Young, J. D., Mangan, J. L. and Tocker, Elizabeth M. An inherited arginase deficiency in sheep erythrocytes 
Fetuga, B. L., Babatunde, G. M. and Oyenuga, V. A. The value of palm kernel meal in finishing diets for pigs. 1 . The effect of varying the proportion of protein contribution from blood meal and palm kernel meal on the performance and carcass quality of finishing pigs

Fetuga, B. L., Babatunde, G. M. and Oyenuga, V. A. The value of palm kernel meal in finishing diets for pigs. 2. The effects of the addition of cane molasses on the utilization

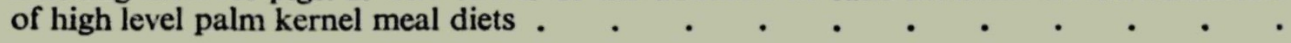

SyKes, A. R. and COOP, R. L. Intake and utilization of food by growing sheep with abomasal damage caused by daily dosing with Ostertagia circumcincta larvae . . • . .

Obigbesan, G. O., Ketiku, A. O. and Fayemi, A. A. Effects of age at harvest and fertilizer application on the yield, available carbohydrates and hydrocyanic acid content of cassava (Manihot palmata Pohl)

Armstrong, R. H. and Eadie, J. The growth of hill lambs on herbage diets . • .

Degen, A. A. Fat-tailed Awassi and German Mutton Merino sheep under semi-arid conditions. 1. Total body water, its distribution and water turnover .

Degen, A. A. Fat-tailed Awassi and German Mutton Merino sheep under semi-arid conditions. 2. Total body water and water turnover during pregnancy and lactation .

Mussa, A. E. A. and Russell, P. E. The influence of pesticides and herbicides on the growth and virulence of Fusarium solani f.sp. phaseoli .

Bartholomew, P. W. and Chestnutr, D. M. B. The effect of a wide range of fertilizer nitrogen application rates and defoliation intervals on the dry-matter production, seasonal response to nitrogen, persistence and aspects of chemical composition of perennial ryegrass (Lolium perenne cv. S. 24)

Badhoria, B. S., Aggarival, G. C. and Tripathi, B. R. An inexpensive device for recording seedling emergence force .

Smithson, J. B. and Gridley, H. E. Oil content of cotton seed in Northern Nigeria. 1. Assessment of nuclear magnetic resonance for the determination of the oil percentage of cotton seed

Gridley, H. E. and Smithson, J. B. Oil content of cotton seed in Northern Nigeria. 2. Varietal

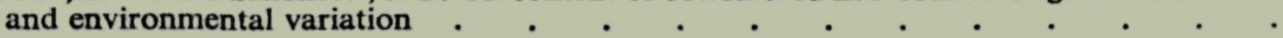

ONWUEME, I. C. Effect of varying the time of the first harvest, and of late planting, on doubleharvest yield of yam (Dioscorea rotundata) in field plots . . . . . . .

EL-Karouri, M. O. H. and Gooderham, P. T. The effect of soil physical conditions and nitro-

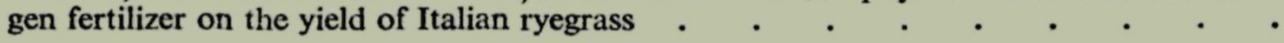

Bed, A. S. and SeKhon, G. S. Effect of potassium and magnesium application to soils on the dry-matter yield and cation composition of maize $\quad \cdot \quad \cdot \quad \cdot \quad \cdot \quad \cdot$.

DahiYa, B. S., Brar, J. S. and BAJAJ, R. K. Regressions, correlations and combining ability of some quantitative characters in peas (Pisum sativum L.).${ }^{\prime} \cdot{ }^{\prime} \cdot{ }^{\prime}$.

Wright, P. C., Young, J. D., Mangan, J. L. and Tucker, Elizabeth M. An inherited arginase deficiency in sheep erythrocytes 


\section{THE JOURNAL OF AGRICULTURAL SCIENCE}

\section{CONTENTS}

\section{Vol. 88 Part 3 June 1977}

Benjumin, R. W., Chin, M., Degen, A. A., Abdul Aziz, N. and Al Hadad, M. J. Estimation of the dry- and organic-matter intake of young sheep grazing a dry Mediterranean pasture and their maintenance requirements .

AGrsB, O. A. A. and AYous, A.T. Effect of sowing date and soil type on plant survival and grain yield of chick peas (Cicer arietinum L.)

PAOE

513

521

Ashron, W. M., Wrliams, Myrtub and Inoleton, Jran. Studies on ewe's milk. VI. The content of some trace elements

Litre, D. A., MCLean, R. W. and Winter, W. H. Prediction of the phosphorus content of herbage consumed by grazing cattle.

Robinson, J. J., McDonald, I., Fraser, C. and Crofts, R. M. J. Studies on reproduction in prolific ewes. 1. Growth of the products of conception

WrNHaM, G. Studies on reproduction in prolific ewes. 2. A radiographic study of the primary and secondary ossification centres in the foetus

Scarisbrick, D. H., WILKRS, J. M and Kempson, R. The effect of varying plant population density on the seed yield of Navy beans (Phaseolus vulgaris) in south-east England.

Penning, P. D., Pennning, Ines M. and Treacher, T. T. The effect of temperature and method of feeding on the digestibility of two milk substitutes and on the performance of lambs

Singh, Ranjodh, Chadha, R. K., Verma, H. N. and Singh, Yavdinder. Response of dryland wheat to phosphorus fertilizer as influenced by profile water storage and rainfall

Lysons, R. J., Albxander, T. J. L. and Wellstead, Patricla D. Nutrition and growth of gnotobiotic lambs

Hebrlethwarte, P. D. Irrigation and nitrogen studies in S. 23 ryegrass grown for seed. 1. Growth, development, seed yield components and seed yield

Hebblethwarte, P. D. and MCGowaN, M. Irrigation and nitrogen studies in S. 23 ryegrass grown for seed. 2. Crop transpiration and silo-water status . . . . . .

Hundal, H.S., Deol, P.S. and Szkhon, G. S. Evaluation of some sources of fertilizer phosphorus in two cycles of a paddy-wheat cropping sequence

Hodoson, D. R., Proud, J. R. and Browne, S. Cultivation systems for spring barley with special reference to direct drilling (1971-1974).

Merrez, A. Z. and Ørsxov, E. R. A study of the artificial fibre bag technique for determining the digestibility of feeds in the rumen

FAHMY, M. H. and VesELY, J. A. Wool yield and characteristics of Dorset, Leicester and Suffolk breeds and their 'DLS' cross

Continued on inside back cover

Cambridge University Press 1977

SUbSCRIPTIONs. Two volumes of three parts are published annually. The subscription price of volumes 88 and 89, 1977, is $£ 22.00$ net (U.S.A. and Canada US 851.00 ) per volume (post free); single parts are available at $\mathbf{1 9 . 0 0}$ net (U.S.A. and Canada US $\mathbf{\$ 2 1 . 0 0}$ ) plus postage. Orders or enquiries may be sent to any bookseller or subscription agent, or to Cambridge University Press, P.O. Box 92, London NW1 2DB (U.S.A. and Canada, Cambridge University Press, 32 East 57th Street, New York, N.Y. 10022, U.S.A.). 